\title{
Pit-1 is expressed in normal and tumorous human breast and regulates GH secretion and cell proliferation
}

\author{
C Gil-Puig ${ }^{1}, S_{\text {Seoane }}{ }^{1}$, M Blanco $^{2}$, M Macia ${ }^{3}$, T Garcia-Caballero ${ }^{2}$, C Segura $^{2}$ and R Perez-Fernandez ${ }^{1}$ \\ Departments of ${ }^{1}$ Physiology, ${ }^{2}$ Morphological Sciences and ${ }^{3}$ Obstetrics and Gynecology, School of Medicine, University of Santiago de Compostela, \\ 15782 Santiago de Compostela, Spain \\ (Correspondence should be addressed to R Perez-Fernandez; Email: fsropefe@usc.es)
}

\begin{abstract}
Background: The transcription factor pituitary-1 (Pit-1) is mainly expressed in the pituitary gland, where it has critical roles in cell differentiation and as a transcriptional factor for $\mathrm{GH}$ and prolactin (PRL). It is also expressed in human extrapituitary tissues (placenta, lymphoid and haematopoietic tissues) and cell lines (human breast adenocarcinoma cells, MCF-7). Despite the widely suggested roles of $\mathrm{GH}$ and PRL in the progression of proliferative mammary disorders, Pit-1 expression in human mammary gland has not yet been reported.

Objective: To evaluate the expression of Pit-1 in human breast and, using the MCF-7 cell line, to investigate whether Pit-1 overexpression regulates GH expression and increases cell proliferation.

Methods: Using real-time RT-PCR, western blotting and immunohistochemistry, we evaluated the expression of Pit-1 mRNA and protein in seven normal human breasts and 14 invasive ductal mammary carcinomas. GH regulation by Pit-1 in MCF-7 cells was evaluated using RT-PCR, western blotting, ELISA and transfection assays. Cell proliferation was evaluated using bromodeoxyuridine. Results: We found expression of Pit-1 mRNA and protein in both normal and tumorous human breast. We also found that Pit-1 mRNA levels were significantly increased in breast carcinoma compared with normal breast. In MCF-7 cells, Pit-1 overexpression increased GH mRNA and protein concentrations and significantly increased cell proliferation.

Conclusions: These findings indicate that Pit-1 is expressed in human breast, that it regulates endogenous human mammary GH secretion, and that it increases cell proliferation. This suggests that, depending on its level of expression, Pit-1 may be involved in normal mammary development, breast disorders, or both.
\end{abstract}

European Journal of Endocrinology 153 335-344

\section{Introduction}

Pit-1/growth hormone (GH) factor-1 (Pit-1) is a pituitary-specific transcriptional factor that has been shown to play a critical part both in cell differentiation during organogenesis of the anterior pituitary in mammals $(1,2)$ and as a transcriptional activator for pituitary gene transcription (3-5). In coordinate action with additional factors, it is responsible for the specification, expansion and survival of three specific cell types (somatotropes, lactotropes and a subset of thyrotropes) during anterior pituitary development (6-8), and for the transcriptional regulation of target promoters (GH, prolactin (PRL), $\beta$ subunit of thyroidstimulating hormone (TSH), GH releasing hormone (GHRH) receptor genes, and the Pit-1 gene itself) (3, 4, $6-10)$. Mice with inactivating mutations or deletions of the Pit-1 gene fail to generate somatotropes, lactotropes and thyrotropes, and consequently exhibit anterior pituitary hypoplasia and dwarfism (6), demonstrating the importance of Pit-1 in the ontogeny of the pituitary gland. Expression of Pit-1 transcripts and protein is highly regulated, and the presence of Pit-1 protein is correlated both temporally and spatially with activation of the GH gene during pituitary development (2).

Pituitary tumors show greater expression of Pit-1 than does normal pituitary, suggesting a possible role in the pathogenesis of pituitary tumors $(11-13)$. In addition, Pit-1 antisense oligonucleotides not only block GH and PRL transcription, but also inhibit the incorporation of $\left[{ }^{3} \mathrm{H}\right]$ thymidine by somatotroph and lactotroph cell lines, suggesting that Pit-1 may regulate DNA replication and cell proliferation (14).

However, little is known about the role of Pit-1 in human extrapituitary tissues such as mammary gland. One study did not reveal Pit-1 mRNA in normal canine mammary tissues despite the presence of $\mathrm{GH}$ gene transcripts, but GH-expressing canine 
mammary tumors showed Pit-1 expression, suggesting a role for Pit-1 in mammary expression of $\mathrm{GH}$ after malignant transformation (15). In relation to this possibility, a relationship has been suggested between PRL, GH, insulin-like growth factor (IGF)-I and breast cancer (for reviews see 16,17). GH and PRL, together with the corresponding mRNAs and receptors, have been found in both normal human breast and mammary tumors (18-22). Treatment with GH induces mammary gland hyperplasia in ageing primates, which may be a consequence either of increased concentrations of IGF-I induced by GH, or of a direct action of $\mathrm{GH}$ through the epithelial PRL receptor (23). In addition, a positive correlation between circulating IGF-I concentration and risk of breast cancer has been found in premenopausal women (24). In spite of these data, however, Pit-1 has not been described in human normal breast or mammary tumors. We have previously demonstrated the expression of Pit-1 and GH in the MCF-7 human breast adenocarcinoma cell line (25), suggesting that Pit-1 may act directly or through GH to induce cell proliferation. In the present study, we looked for the expression of Pit-1 in normal human mammary gland and in human invasive ductal mammary carcinoma. In addition, using the MCF-7 cell line, we evaluated whether experimental overexpression of Pit-1 induces cell proliferation or $\mathrm{GH}$ secretion, or both.

\section{Materials and methods}

\section{Specimens}

Fresh samples of human normal breast $(n=7)$, classic (not otherwise specified (NOS)) invasive ductal carcinoma $(n=14)$, placenta $(n=2)$ and pituitary gland were obtained from the Pathology Department of the Complejo Hospitalario Universitario de Santiago de Compostela (Spain), in line with institutional Ethics Committee approval. Rat adrenal gland and rat pituitary Pit-1 protein (Santa Cruz Biotechnology, Santa Cruz, CA, USA) were used as controls. A small part of the tissues was frozen in liquid nitrogen and stored at $-80^{\circ} \mathrm{C}$, and the remainder (normal and tumorous breast) was immersion-fixed in $10 \%$ buffered formalin for $24 \mathrm{~h}$, dehydrated and embedded in paraffin by a standard procedure.

\section{Cell culture}

The MCF-7 human breast adenocarcinoma cell line and the Saos-2 human osteosarcoma cell line were obtained from the European Collection of Cell Cultures (Salisbury, Wilts, UK). Stock cultures were grown in $90 \mathrm{~mm}$ Petri dishes in Dulbecco's modified Eagle's medium (DMEM) supplemented with 10\% fetal bovine serum, $100 \mathrm{U} / \mathrm{ml}$ penicillin, $100 \mu \mathrm{g} / \mathrm{ml}$ streptomycin (for both MCF-7 and Saos- 2 cells) and $2 \mathrm{mmol} / \mathrm{l} \mathrm{L-gluta-}$ mine (MCF-7 cells only) in an atmosphere of 95\% air
$-5 \% \quad \mathrm{CO}_{2}$ at $37^{\circ} \mathrm{C}$. Confluent cells were washed twice with PBS and harvested by a brief incubation with trypsin-EDTA solution (Sigma) in PBS.

\section{Isolation of RNA and RT-PCR analysis}

Isolation of total RNA from tissues and from the MCF-7 cell line was performed with the TRIzol reagent (Invitrogen) according to the manufacturer's instructions. RT-PCR was performed as described previously (Gil-Puig et al. 2002). Briefly, cDNA synthesis was as follows: $2 \mu \mathrm{g}$ total RNA was incubated for $50 \mathrm{~min}$ at $37^{\circ} \mathrm{C}, 15 \mathrm{~min}$ at $42^{\circ} \mathrm{C}$ and $5 \mathrm{~min}$ at $95^{\circ} \mathrm{C}$ with 400 units of Moloney murine leukaemia virus reverse transcriptase (Invitrogen) in buffer $(50 \mathrm{mmol} / \mathrm{l}$ Tris- $\mathrm{HCl}, \mathrm{pH}$ 8.3; $50 \mathrm{mmol} / \mathrm{l} \mathrm{KCl,} 10 \mathrm{mmol} / \mathrm{l} \mathrm{MgCl}_{2}$ ) containing each deoxynucleotide triphosphate at $2 \mathrm{mmol} / \mathrm{l}, 20$ units RNAse inhibitor (Gene Craft, Münster, Germany) and $500 \mathrm{ng}$ random primers (Invitrogen) in a total volume of $30 \mu \mathrm{l}$. Five microlitres of the cDNA generated under these conditions were amplified by PCR using 2 units Taq polymerase (Gene Craft) in a buffer containing $50 \mathrm{mmol} / \mathrm{l} \mathrm{KCl}, 10 \mathrm{mmol} / \mathrm{l}$ Tris- $\mathrm{HCl}(\mathrm{pH} \mathrm{9.0)}$ and $1.5 \mathrm{mmol} / \mathrm{l} \mathrm{MgCl}_{2}$, with each deoxynucleotide triphosphate at $0.2 \mathrm{mmol} / \mathrm{l}$ and each of two oligonucleotide primers at $25 \mathrm{pmol} / \mathrm{l}$, to a total volume of $50 \mu \mathrm{l}$. The sample was denatured at $94^{\circ} \mathrm{C}$ for $1 \mathrm{~min}$, annealed at $58,57,64$ or $60^{\circ} \mathrm{C}$ for $1 \mathrm{~min}$ (Pit-1, GH, IGF-I and $18 \mathrm{~S}$, respectively), and extended at $72{ }^{\circ} \mathrm{C}$ for $1 \mathrm{~min}$, for a total of 35 cycles, with an extension step of $10 \mathrm{~min}$ at $72^{\circ} \mathrm{C}$ in the final cycle.

For quantification of mRNA in each sample, PCR products were separated on $2 \%$ agarose gel, stained with ethidium bromide, examined with u.v. light and quantified using the Gel Doc 1000 Documentation System (Bio-Rad Laboratories). To determine the relative amounts of Pit-1 mRNA or GH mRNA in each sample, absolute amounts were expressed relative to $18 \mathrm{~S}$ mRNA amounts.

\section{Analysis of Pit-1 gene expression by real-time RT-PCR}

Pit-1, IGF-I and 18S mRNA levels were quantified using real-time PCR in a fluorescent temperature cycler (LightCycler, Roche Molecular Biochemicals) according to the manufacturer's instructions. The $20 \mu \mathrm{l}$ amplification mixture contained $2 \mu \mathrm{l}$ RT reaction products (obtained as described above) plus $\mathrm{MgCl}_{2}$ at $4 \mathrm{mmol} / \mathrm{l}$, each primer at $0.5 \mu \mathrm{mol} / \mathrm{l}$, and $2 \mu \mathrm{l}$ LightCycler DNA Master SYBR Green I mix (Roche Molecular Biochemicals). After initial denaturation at $94{ }^{\circ} \mathrm{C}$ for $30 \mathrm{~s}$, reactions were cycled 40 times as follows: denaturation at $95^{\circ} \mathrm{C}$ for $2 \mathrm{~s}$, annealing at 60,64 or $58^{\circ} \mathrm{C}(18 \mathrm{~S}$, IGF-I or Pit-1, respectively) for $10 \mathrm{~s}$, and extension at $72{ }^{\circ} \mathrm{C}$ for $15 \mathrm{~s}$. The amount of PCR products formed in each cycle was evaluated on the basis of SYBR Green fluorescence. At the end of each run, melting-curve profiles 
were produced (cooling the sample to $68^{\circ} \mathrm{C}$ and heating slowly to $95^{\circ} \mathrm{C}$, with continuous measurement of fluorescence) to confirm amplification of specific transcripts (data not shown). Cycle-to-cycle fluorescence emission readings were monitored and quantified using the second derivative maximum method of the LightCycler software package (Roche Molecular Biochemicals). This method determines the crossing points of individual samples by an algorithm that identifies the first turning point of the fluorescence curve. This turning point corresponds to the first maximum of the second derivative curve and correlates inversely with the $\log$ of the initial template concentration. Pit-1 and IGF-I mRNA levels were normalized with respect to $18 \mathrm{~S}$ level in each sample.

\section{Primer sequences}

Primer sequences for Pit-1 PCR amplification were: primer A (5'-GTGTCTACCAGTCTCCAACC-3'), a 20mer corresponding to nucleotides 570-589 in exon 1 of Pit- 1 cDNA, and primer B (5'-ACTTTTCCGCCTGAGTTCCT-3'), an antisense 20-mer corresponding to nucleotides 269-288 in exon 3 of Pit-1 cDNA; the PCR product obtained was $247 \mathrm{bp}$ long. Primer sequences for GH PCR amplification were: primer A (5'-CCGACACCCTCCAACAGGGA-3'), a 20-mer corresponding to nucleotides $314-334$ in exon 3 of $\mathrm{GH}$ cDNA, and primer B (5'-CCTTGTCCATGTCCTTCCTG$3^{\prime}$ ), a 20-mer corresponding to nucleotides 638-658 in exon 5 of GH cDNA; the PCR product obtained was 344 bp long. Primer sequences for IGF-I PCR amplification were: primer A (5'-AGCAGTCTTCCAACCCAATTATTT-3'), a 24-mer corresponding to nucleotides 24-47 in the cDNA coding IGF-I, and primer B (5'AGATGCGAGGAGGACATGGT-3'), an antisense 20mer corresponding to nucleotides 87-106 in the cDNA coding IGF-I; the PCR product obtained was 83 bp long. Human $18 \mathrm{~S}$ ribosomal RNA (26) was used as internal reference. Primer sequences were: forward primer 5'-GTAACCCGTTGAACCCCATT-3', and reverse primer 5'-CCATCCAATCGGTA GTAGCG-3'; the PCR product obtained was $131 \mathrm{bp}$ long.

\section{Western blot analysis of Pit-1 in breast tissue and Pit-1 and GH in MCF-7 cells}

Tissues were homogenized at $4^{\circ} \mathrm{C}$ in $3 \mathrm{ml}$ lysis buffer $(1 \times$ PBS; $1 \%$ Nonidet, $0.5 \%$ deoxycholic acid; $0.1 \%$ SDS; $100 \mathrm{mmol} / \mathrm{l}$ sodium orthovanadate; $10 \mathrm{mg} / \mathrm{ml}$ phenyl methylsulphonyl fluoride (PMSF) and $100 \mathrm{mmol} / \mathrm{l}$ aprotinin). MCF-7 cells (or Saos-2, used as control) were lysed at $4^{\circ} \mathrm{C}$ in $1 \mathrm{ml}$ lysis buffer ( $50 \mathrm{mmol} / \mathrm{l} \mathrm{Hepes,} \mathrm{pH} \mathrm{7.5;} 150 \mathrm{mmol} / \mathrm{l} \mathrm{NaCl} ; 5 \mathrm{mmol} / \mathrm{l}$ EGTA; $1.5 \mathrm{mmol} / \mathrm{l} \mathrm{MgCl} 2 ; 1 \%$ SDS; $10 \%$ glycerol; $1 \%$ Triton X-100; $10 \mathrm{mmol} / \mathrm{l}$ sodium orthovanadate; $4 \mathrm{mmol} / \mathrm{l}$ PMSF and $50 \mu \mathrm{g} / \mathrm{ml}$ aprotinin) and sonicated. The cell lysate was then centrifuged at $17000 \mathrm{~g}$ for
$15 \mathrm{~min}$ at $4^{\circ} \mathrm{C}$, the resulting supernatant was collected, and protein concentration was determined by the Bradford method. Lysate supernatant containing $1.5 \mathrm{mg}$ total protein (adenocarcinomas and MCF-7 cells) or $2 \mathrm{mg}$ total protein (normal mammary tissue) was immunoprecipitated with a monoclonal anti-Pit-1 antibody (Transduction Laboratories, Lexington, KY, USA) and incubated overnight at $4^{\circ} \mathrm{C}$. Thirty microlitres ProteinG-Sepharose (Gammbind G Sepharose, Amersham Pharmacia Biotech) was then added and incubated for $45 \mathrm{~min}$. The samples were centrifuged at $17000 \mathrm{~g}$ for $3 \mathrm{~min}$ and the pellet washed five times with buffer (Hepes $20 \mathrm{mmol} / \mathrm{l}$, pH 7.5; $150 \mathrm{mmol} / \mathrm{l} \mathrm{NaCl}, 10 \%$ glycerol, $0.1 \%$ Triton X-100). Pit-1 protein obtained in this way (or $80 \mu \mathrm{g}$ total protein from MCF-7 cells for $\mathrm{GH}$ determination) was then resuspended in $2 \times$ SDSsample buffer ( $50 \mathrm{mmol} / \mathrm{l}$ Tris-HCl, pH 6.8; 50\% glycerol, $2 \%$ SDS, $2 \%$-mercaptoethanol, and bromophenol blue) and boiled for $5 \mathrm{~min}$. The samples were subjected to 12 or 15\% SDS-PAGE electrophoresis (for Pit-1 and GH, respectively). Proteins were transferred to a nitrocellulose membrane for $2 \mathrm{~h}$ at $4^{\circ} \mathrm{C}$. Nitrocellulose membranes were blocked with $0.1 \mathrm{~g}$ casein in PBS with $0.1 \%$ Tween 20 (PBST) for $2 \mathrm{~h}$ at room temperature. Blots were then immunolabelled overnight at $4{ }^{\circ} \mathrm{C}$ with a polyclonal anti-Pit-1 antiserum (1:500) (Santa Cruz Biotechnology) or with a polyclonal anti-hGH antibody (1:4000; from Dr A Parlow, National Hormone \& Peptide Program, Torrance, CA, USA). After five washes for 5 min each in PBST, membranes were incubated with goat anti-rabbit IgG (1:5000) alkaline-phosphataseconjugated second antibody, using CSPD (Tropix, PE Biosystem, Bedford, MA, USA) as substrate, for $1 \mathrm{~h}$ at room temperature. The membrane was further washed five times for 5 min each time in PBST before immunolabelling. Immunolabelling was detected by placing the blot on standard X-ray film according to the manufacturer's instructions (Tropix). To confirm that equivalent amounts of total protein were added to each well, membranes were stripped by incubation in $0.2 \mathrm{~mol} / \mathrm{l}$ glycine, $\mathrm{pH} 2.5$, containing $0.1 \%$ SDS and 1\% Tween 20 at room temperature for $1 \mathrm{~h}$, and then re-probed with an anti- $\beta$-actin monoclonal antibody (1:2000; Sigma).

\section{Immunohistochemistry}

Paraffin sections $5 \mu \mathrm{m}$ thick were mounted on 3-aminopropyl-triethoxysilane-coated slides and deparaffinized before processing for immunohistochemistry with an anti-Pit-1 (X-7) affinity-purified rabbit polyclonal antiserum (Santa Cruz Biotechnology). This antibody was raised against a polyhistidine fusion protein construct containing sequences corresponding to fulllength Pit-1 of rat origin. The antigen was retrieved by microwaving at $750 \mathrm{~W}$ for $10 \mathrm{~min}$ in $0.01 \mathrm{~mol} / \mathrm{l}$ trisodium citrate buffer, $\mathrm{pH}$ 6.0. The streptavidin-biotin complex immunohistochemical method was used and the sections were consecutively incubated in: (1) 3\% 
hydrogen peroxide for $10 \mathrm{~min}$ (Merck, Darmstadt, Germany) in order to block endogenous peroxidase activity; (2) the anti-Pit-1 antiserum at a dilution of 1:50 for $1 \mathrm{~h}$; (3) biotinylated goat antibodies to mouse/rabbit immunoglobulins (Duet kit, Dakopatts, Glostrup, Denmark) at a dilution of 1:100, for $30 \mathrm{~min}$; (4) streptavidin-biotin-peroxidase complex (Duet kit, Dakopatts) prepared according to the procedure provided by the manufacturer, for $30 \mathrm{~min}$; and (5) 3,3'-diamino-benzidine-tetrahydrochloride (DAB) solution prepared by dissolving one DAB-buffer tablet (Merck) in $10 \mathrm{ml}$ distilled water, for $10 \mathrm{~min}$. All incubation steps were performed at room temperature. Between steps, the sections were washed twice for $5 \mathrm{~min}$ with PBS $(0.01 \mathrm{~mol} / \mathrm{l}$ phosphate buffer, $\mathrm{pH} 7.4$, containing $0.15 \mathrm{~mol} / \mathrm{l} \mathrm{NaCl}$ ), and with distilled water after step 5. All dilutions were in PBS, containing $0.1 \%$ BSA (Sigma) for dilution of the primary antibody (step 1) and 1.5\% normal goat serum (Dakopatts) for dilution of the biotinylated antibodies (step 3). No counterstaining was done. Controls for the specificity of immunohistochemistry included preadsorption of the primary antibody with $20 \mu \mathrm{mol} / \mathrm{l}$ Pit-1 (overnight at $4^{\circ} \mathrm{C}$ ), and replacement of the primary antibody or other essential reagents with PBS.

\section{Incorporation of bromodeoxyuridine}

MCF-7 cells were cultured as described above and then $20 \times 10^{3}$ cells per well were seeded in 24-well dishes, covered with coverslides, and allowed to attach overnight. Transfections were carried out in wells containing $0.8 \mu \mathrm{l}$ Fugene (Roche Molecular Biochemicals), $275 \mathrm{ng}$ total DNA, pRSVhPit-1 expression vector (10, $50,100,250,500$ or $1000 \mathrm{ng}$ ) or the same amount of pRc/RSV empty vector (control cells), and $25 \mathrm{ng}$ pEPuro (conferring puromycin resistance). Control and treated cells were selected using $1 \mu \mathrm{g} / \mathrm{ml}$ puromycin, and incubated for $72 \mathrm{~h}$. Resistant cells were then labelled with $10 \mu \mathrm{mol} / \mathrm{l}$ bromodeoxyuridine (BrdU) for $30 \mathrm{~min}$. Cells were fixed overnight in ethanol, permeabilized in $0.07 \mathrm{~mol} / \mathrm{l} \mathrm{NaOH}$, and incubated overnight at $4{ }^{\circ} \mathrm{C}$ with 1:100 $\alpha$-BrdU (BD Biosciences, San Diego, CA, USA), followed by 1:150 F(ab) IgG:fluorescein isothiocyanate (Jackson Immunoresearch, West Grove, PA, USA) plus 4,6-diamine-2-phenylindole for $45 \mathrm{~min}$ at $37^{\circ} \mathrm{C}$ in a humidified chamber.

\section{Plasmids, transfections and luciferase assay}

The pRSVhPit-1 expression vector was a kind gift from Dr JL Castrillo. The $5^{\prime}$ flanking region of the human GH $(h G H)$ gene was obtained from the pUC8-hGH plasmid and fused to the pGL3-Basic vector (Promega) as described previously (27). MCF-7 human breast adenocarcinoma cells were cultured as described above. Between 12 and $24 \mathrm{~h}$ before transfection, the cells were cultured in DMEM containing 10\% charcoal-stripped fetal calf serum; $15 \times 10^{4}$ cells per well were then seeded in six-well dishes and allowed to attach overnight. To evaluate GH mRNA and protein expression, MCF-7 cells were transfected with $1 \mu \mathrm{g}$ pRSVhPit-1 construct and incubated for 24, 48 or $72 \mathrm{~h}$. Isolation of total RNA, RT-PCR and western blotting were performed as described above.

Transient transfections were carried out in wells containing $5.4 \mu \mathrm{l}$ Fugene (Roche), $500 \mathrm{ng}$ hGH promoterluc construct (pGL3-basic- $\mathrm{GH}_{300}$ ), 100, 250, 500 or $1000 \mathrm{ng}$ pRSVhPit-1 expression vector, and $0.3 \mu \mathrm{g}$ Rous sarcoma virus $\beta$-galactosidase (pRSV- $\beta$-gal). Each experiment was performed in triplicate cultures. The cells were incubated for $72 \mathrm{~h}$ in hormone-depleted medium, harvested in lysis buffer (Passive Lysis $5 \times$ buffer, Promega), and luciferase activity was then measured using a luminometer. $\beta$-Galactosidase activity was measured on the basis of absorbance at $420 \mathrm{~nm}$ using $o$-nitrophenyl- $\beta$-D-galactopyranoside as substrate.

\section{ELISA for GH}

MCF-7 cells were grown to confluence in 24-well plates as described above. The amount of hGH secreted into $250 \mu \mathrm{l}$ serum-free medium after transfection with $250 \mathrm{ng}$ pRSVhPit-1 per well was estimated over 24-, 48- and 72-h periods by ELISA using the hGH ELISA kit (Roche) according to the manufacturer's instructions.

\section{Statistical analysis}

Each experiment was performed at least three times. All values are expressed as means \pm s.D. Means were compared by unpaired $t$-tests or one-way analysis of variance with the Tukey-Kramer multiple comparison test for post-hoc comparisons. Statistical significance was taken to be indicated by $P<0.05$.

\section{Results}

\section{Detection of Pit-1 mRNA and protein in human invasive ductal mammary carcinoma and normal breast}

PCR amplification of cDNA prepared from human mammary adenocarcinoma, normal mammary gland, human placenta or pituitary gland gave a $247 \mathrm{bp}$ PCR product corresponding to human Pit-1 (33 kDa) (Fig. 1). The PCR products were sequenced to confirm the identity of Pit-1. The sequence was identical to that of pituitary Pit-1.

To evaluate the levels of expression of Pit-1 mRNA in normal breast and mammary tumors, we calculated Pit-1 mRNA levels with respect to $18 \mathrm{~S}$ mRNA levels, as determined by real-time RT-PCR. The Pit-1 mRNA level in patients with invasive ductal mammary carci- 
A

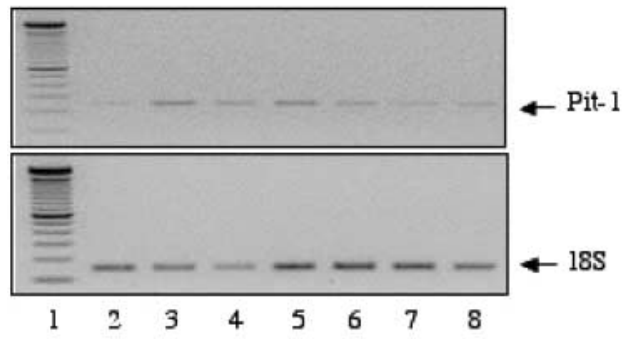

B
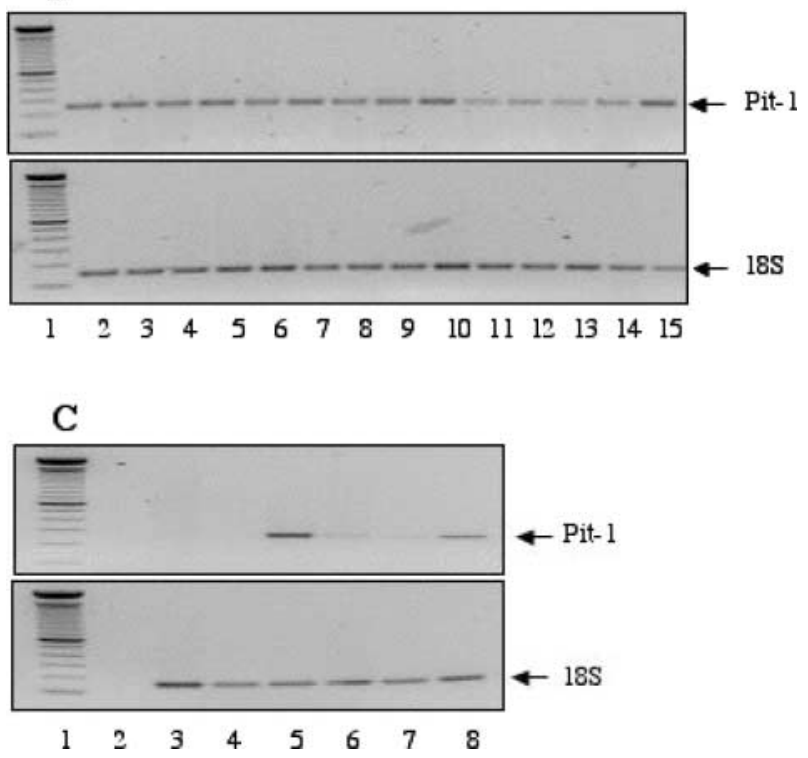

Figure 1 Pit-1 mRNA is expressed in normal breast and in invasive ductal tumors. (A) Pit-1 and 18S PCR products obtained from seven normal mammary glands (lanes 2-8); lane 1: $1000 \mathrm{bp}$ ladder. (B) Pit-1 and 18S PCR products obtained from 14 invasive ductal mammary carcinomas (lanes 2-15); lane 1: $1000 \mathrm{bp}$ ladder. (C) Representative RT-PCR analysis of normal and tumorous mammary gland. Lane 1: 1000 bp ladder; lane 2: negative control of PCR; lane 3: human osteosarcoma cell line (Saos-2) used as negative control; lane 4: rat adrenal gland (used as negative control); lane 5: human pituitary gland (positive control); lane 6: human placenta (positive control); lane 7: normal breast; lane 8: mammary tumor.

noma (2.58 \pm 0.36$)$ was significantly increased with respect to that in normal breast $(2.14 \pm 0.17)$ $(P<0.01)$. Pit-1 mRNA levels were also determined by semi-quantitative analysis. The results obtained $(0.67 \pm 0.07$ in normal breast and $0.98 \pm 0.21$ in invasive ductal mammary carcinoma) are in accordance with those obtained by real-time RT-PCR - that is, there were significant differences $(P<0.01)$ between the levels of expression of Pit-1 mRNA in tumour and normal breast.

Samples from normal breast and from mammary carcinomas $(1.5 \mathrm{mg}$ total protein for adenocarcinomas and $2 \mathrm{mg}$ total protein for normal mammary tissue) were immunoprecipitated using a monoclonal
anti-Pit-1 antibody. Two major Pit-1-immunoreactive bands were readily visible in samples from the normal mammary glands (Fig. 2A, lower panel). These bands, which arise from two alternative translation-initiation codons in Pit-1 mRNA, have previously been referred to as the 31 and $33 \mathrm{kDa}$ bands (28). Western blots also clearly showed similar immunoreactive bands in samples from adenocarcinomas (Fig. 2A, upper panel). We also performed western blots for Pit-1 protein detection in Saos-2 (a human osteosarcoma cell line) and rat adrenal gland, but did not find significant expression of Pit-1 (Fig. 2B). As positive controls, we used human placenta and rat pituitary Pit-1 (Fig. 2B). This was an immunoprecipitation-based procedure and we thus have no way of evaluating the concentration of Pit-1 relative to a protein standard; however, these results certainly suggest that expression of Pit- 1 is greater in breast tumors than in normal mammary gland.

Immunohistochemistry revealed Pit-1 immunoreactivity in both normal breast and carcinoma samples. Normal mammary gland showed nuclear immunostaining in both epithelial and myoepithelial cells of the ductal-lobular system (Fig. 3A). No immunolabelling was seen in the negative controls performed to confirm the specificity of the technique (Fig. 3B). All 14 invasive ductal carcinomas studied showed diffuse immunostaining for Pit-1 (Fig. 3C). As in their normal counterpart, the signal was found in the nuclei of tumor cells (Fig. 3D).

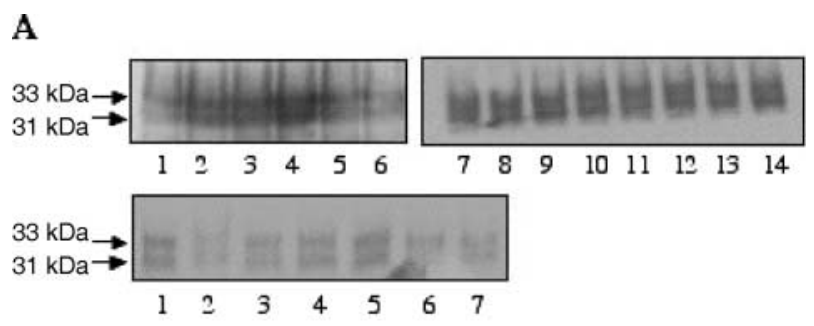

B

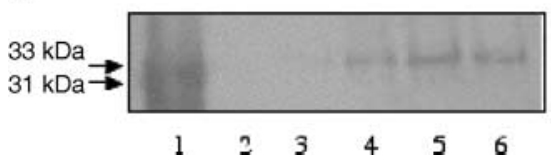

Figure 2 Western blot analysis of immunoreactive Pit-1. (A) Fourteen invasive ductal mammary carcinomas (upper panel, lanes $1-14$ ), and seven normal mammary glands (lower panel, lanes 1-7). As described in Material and methods, $1.5 \mathrm{mg}$ (invasive ductal mammary carcinomas) or $2 \mathrm{mg}$ (normal breast) total protein was immunoprecipitated with a monoclonal anti-Pit-1 antibody, and then used for the analysis. The major 31 and $33 \mathrm{kDa}$ immunoreactive bands are indicated by arrows. (B) Representative western blot of normal and tumorous mammary glands. Lane 1: Rat Pit-1 protein (Santa Cruz Biotechnology) (positive control); lane 2: human osteosarcoma cell line (Saos-2) (negative control); lane 3: rat adrenal gland (negative control); lane 4: human placenta (positive control); lane 5: breast tumor; lane 6: normal mammary gland. 


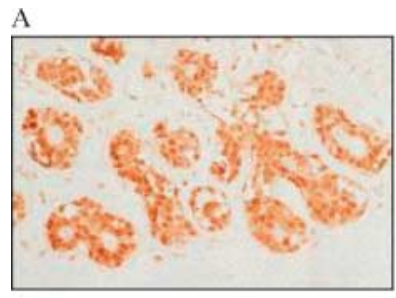

C
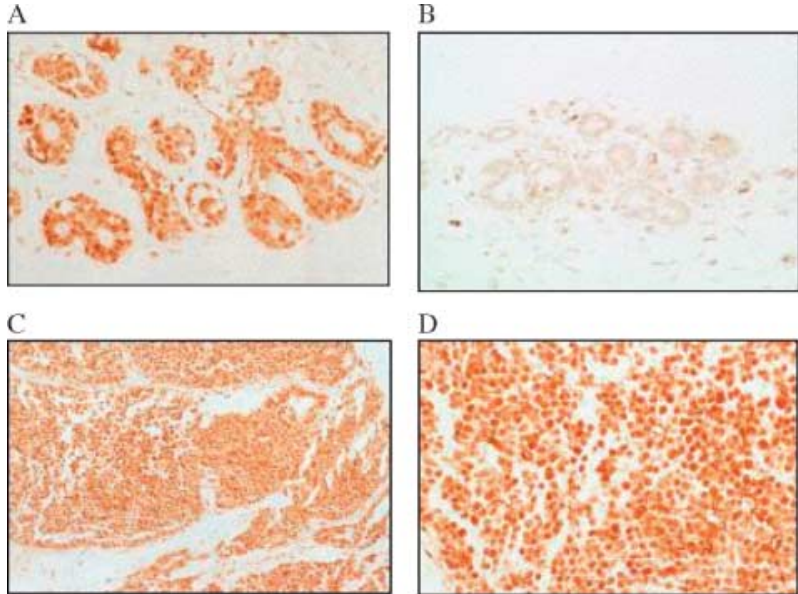

D

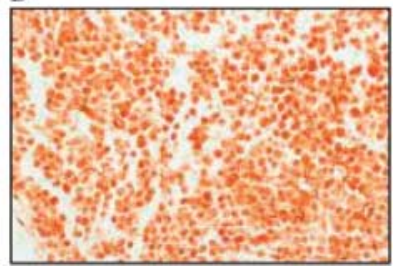

Figure 3 Immunohistochemical detection of Pit-1 in normal mammary gland and in invasive ductal mammary carcinomas. (A) Normal mammary gland immunostained for Pit-1. Nuclear

immunostaining was observed in the double layer of low columnar epithelial cells (inner layer) and contractile myoepithelial cells (outer layer). Original magnification $\times 40$. (B) Negative control in normal mammary gland: the section was incubated with the primary antibody preadsorbed with the homologous antigen (Pit-1), and no immunostaining was observed. Original magnification $\times 40$. (C) Invasive ductal carcinomas showed diffuse Pit- 1 immunostaining. Original magnification $\times 20$. (D) At higher magnification, it can be seen that the immunostaining was located in the nuclei of tumor cells. Original magnification $\times 40$.

\section{Effect of overexpression of Pit-1 on GH and IGF-I mRNA and GH protein levels}

Transfection of MCF-7 cells with the pRSVhPit-1 expression vector induced, as expected, an increase in the expression of Pit-1 protein in these cells, as shown in Fig. 4A. To evaluate whether the increased concentration of Pit- 1 regulates the production of $\mathrm{GH}$, we carried out a PCR amplification of cDNA from MCF-7 human adenocarcinoma cells transfected with pRSVhPit-1 24, 48 or $72 \mathrm{~h}$ previously, using primers for $\mathrm{GH}$. This gave a $344 \mathrm{bp}$ product (Fig. 4B). The results of this analysis indicate a significant $(P<0.001)$ increase in expression of GH mRNA (relative to 18S mRNA expression) at 48 and $72 \mathrm{~h}$ $(1.38 \pm 0.32$ and $1.57 \pm 0.11$, respectively) with respect to untransfected MCF-7 cells $(0.56 \pm 0.11)$ and 24-h-

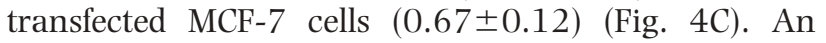
identical procedure was used to assess the effects of the overexpression of Pit-1 on IGF-I mRNA levels, but using primers for IGF-I described above. The results of these experiments indicated no significant differences in expression of IGF-I mRNA between controls (untransfected cells) and pRSVhPit-1-transfected MCF7 cells, at 24,48 or $72 \mathrm{~h}$ (control, $5.1 \pm 0.9 ; 24 \mathrm{~h}$, $5.42 \pm 0.09 ; 48$ h, 5.53 $\pm 0.49 ; 72 \mathrm{~h}, 5.45 \pm 0.15$ ).

Results of western blotting of GH in MCF-7 cells transfected with pRSVhPit-1 are shown in Fig. 5A. GH was detectable in control (untransfected) MCF-7 cells, and in transfected cells, at 24,48 and $72 \mathrm{~h}$.
$\mathbf{A}$

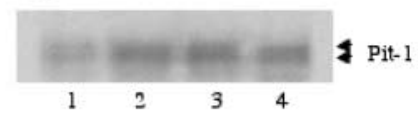

B

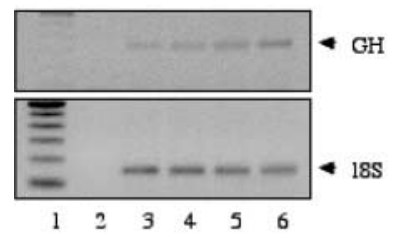

C

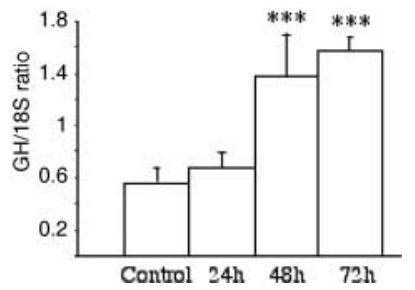

Figure 4 Overexpression of Pit-1 in MCF-7 cells induces increased levels of GH mRNA. (A) Western blot of Pit-1 in pRSVhPit-1-transfected MCF-7 cells. Transfection of pRSVhPit-1 in MCF-7 cells induced, as expected, increased levels of Pit-1 (lane 1: control cells; lane 2: $24 \mathrm{~h}$; lane 3: $48 \mathrm{~h}$; lane 4: $72 \mathrm{~h}$ ). (B) GH and 18S PCR products obtained from pRSVhPit-1-transfected MCF-7 cells. Lane 1: 1000 bp ladder; lane 2: PCR negative control; lane 3: control (untransfected MCF-7) cells; lanes 4, 5 and 6: PCR products of pRSVhPit-1-transfected MCF-7 cells at 24,48 and $72 \mathrm{~h}$, respectively. (C) Relative expression (mean values and S.D. bars) of GH mRNA in pRSVhPit-1 transfected MCF-7 cells and untransfected MCF-7 (control) cells, calculated as $\mathrm{GH}$ densitometry reading divided by $18 \mathrm{~S}$ densitometry reading (B). ${ }^{* * *} P<0.001$.

Significantly increased GH concentrations with respect to control were observed at 48 and $72 \mathrm{~h}(P<0.01)$ (Fig. 5B).

Control cultures of untransfected MCF-7 cells showed low but detectable concentrations of GH protein (evaluated by ELISA) in the medium $(3.01 \pm 2.30 \mathrm{pg} / \mathrm{ml})$ (Fig. 5C). Cultures of MCF-7 cells transfected with pRSVhPit-1 showed greater mean concentrations of $\mathrm{GH}$ than did control cultures from $24 \mathrm{~h}$ onwards $(24 \mathrm{~h}, \quad 4.85 \pm 0.28 \mathrm{pg} / \mathrm{ml} ; \quad 48 \mathrm{~h}, \quad 5.52 \pm 1.53 \mathrm{pg} / \mathrm{ml}$; $72 \mathrm{~h}, 9.52 \pm 3.03 \mathrm{pg} / \mathrm{ml}$ ) (Fig. 5C). The difference was statistically significant at $72 \mathrm{~h}(P<0.01)$, but not before then.

\section{Effect of Pit-1 overexpression on the transcriptional activity of the human GH promoter}

To investigate the effect of Pit- 1 on the transcriptional activity of the GH promoter in the MCF-7 cell line, cells were cotransfected with increasing doses of pRSVhPit-1 and a construct linking $300 \mathrm{bp}$ of the hGH gene promoter to a luciferase reporter vector (pGL3-basic- $\mathrm{GH}_{300}$ ). At $72 \mathrm{~h}$ after transfection, cells were harvested for measurement of luciferase activity. As shown in Fig. 5D, cotransfection with the control plasmid (pGL3-basic) and pRSVhPit-1 had negligible effect on luciferase activity, whereas cotransfection with pGL3-basic- $\mathrm{GH}_{300}$ and pRSVhPit-1 led to a dose-dependent increase in luciferase activity at $72 \mathrm{~h}$, 
confirming our finding that small increases in the concentration of Pit-1 induce increased GH synthesis.

\section{Effect of overexpression of Pit-1 on the proliferation of MCF-7 cells}

MCF-7 cells were transfected at different doses with pRSVhPit-1 expression vector along with a puromycin-resistance-encoding vector (pEPuro), then selected in $1 \mu \mathrm{g} / \mathrm{ml}$ puromycin for $72 \mathrm{~h}$. Cells transfected with pRSVhPit-1 showed a dose-dependent increase in uptake of BrdU with respect to untransfected controls at $72 \mathrm{~h}$ (10 ng pRSVhPit-1: 9.4 $2.1 \%$ compared with $12.8 \pm 5.3 \%$, NS; 50 ng pRSVhPit-1: $10.7 \pm 3.2 \%$ compared with $17.7 \pm 4.4 \%$, NS; $100 \mathrm{ng}$ pRSVhPit-1: $10.1 \pm 3.3 \%$ compared with $25.1 \pm 4.5 \%, P<0.01$; $250 \mathrm{ng}$ pRSVhPit-1: $\quad 12.7 \pm 5.2 \% \quad 26.7 \pm 3.9 \%$, $P<0.01$; 500 ng pRSVhPit-1: $10.9 \pm 2.3 \%$ compared with $29.0 \pm 3.5 \%, \quad P<0.01 ; 1000 \mathrm{ng}$ pRSVhPit-1: $13.8 \pm 5.4 \%$ compared with $33.4 \pm 4.3 \%, P<0.01$ ) (Fig. 6B). Similar results were obtained with $48 \mathrm{~h}$ of puromycin selection (data not shown).
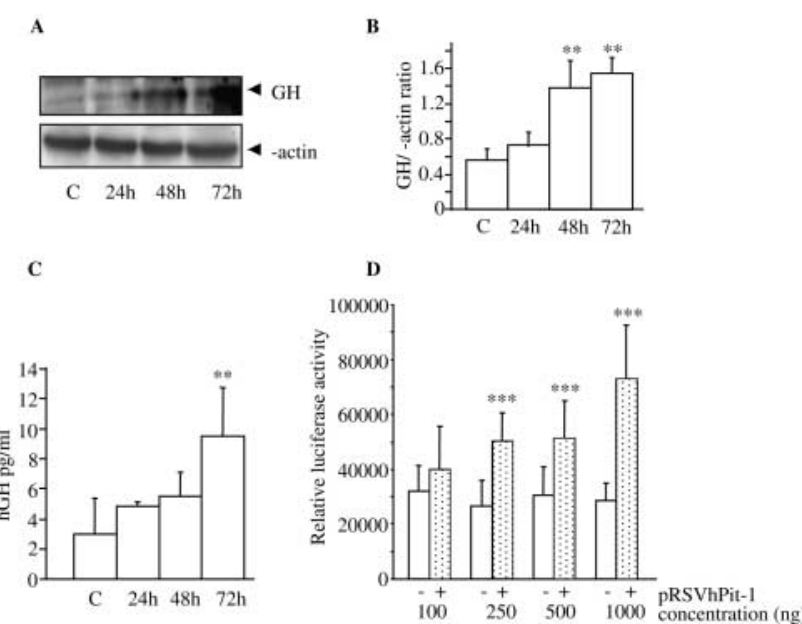

Figure 5 Overexpression of Pit-1 in MCF-7 cells increases GH protein concentrations and activates $\mathrm{GH}$ transcription. (A) Western blot analysis of $\mathrm{GH}$ (upper panel) and $\beta$-actin (lower panel) in control MCF-7 cells and MCF-7 cells transfected with pRSVhPit-1, at 24,48 and $72 \mathrm{~h}$. (B) Densitometric analysis of (A). Relative GH protein concentration was calculated as the $\mathrm{GH} / \beta$-actin ratio from three different experiments. ${ }^{* *} P<0.01$ compared with control cells. (C) GH concentrations, measured by ELISA, in the culture medium of pRSVhPit-1-transfected MCF-7 cells at 24, 48 and $72 \mathrm{~h}$, and in the culture medium of untransfected control MCF-7 cells. ${ }^{*} P<0.01$ compared with control cells. (D) MCF-7 cells cotransfected with different concentrations of pRSVhPit-1 expression vector (100, 250, 500 and 1000 ng/well), pGL3-basic$\mathrm{GH}_{300}$, and $\beta$-galactosidase constructs. Cells were cultured for $72 \mathrm{~h}$. Relative luciferase activity was calculated as the ratio of luciferase activity in cells transfected with pRSVhPit-1 plus pGL3-

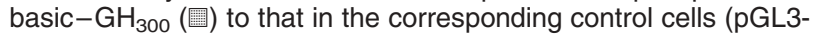
basic plus pRSVhPit-1; $\square$ ). $\beta$-Galactosidase activity was used to correct for transfection efficiency. (B) $-(D)$ show mean values and S.D. bars. ${ }^{* \star} P<0.001$ compared with control cells.

\section{Discussion}

Pit-1 is a key transcriptional factor in pituitary-specific activation of the GH, PRL and TSH genes $(29,30)$. Although it was originally believed to be pituitaryspecific, it is clearly also present in some extrapituitary tissues and cell lines: Pit-1 expression has been demonstrated in human placenta $(31,32)$, human haematopoietic and lymphoid tissues and the HL-60 and RAJI leukaemic cell lines (11), and recently in the MCF-7 human breast adenocarcinoma cell line (25). In normal dog mammary tissue, however, Pit-1 mRNA is not detectable, despite the presence of GH gene transcripts (15); nevertheless, GH-expressing dog mammary tumors showed Pit-1 expression, which suggests that, at least in dogs, expression of the $G H$ gene in mammary tissues is independent of Pit- 1 , at least before malignant transformation (15). No data have been reported to date concerning the expression of Pit-1 in human mammary gland. In the present study, we demonstrated Pit-1 mRNA (by RT-PCR) and Pit-1 protein expression (using both western blot and
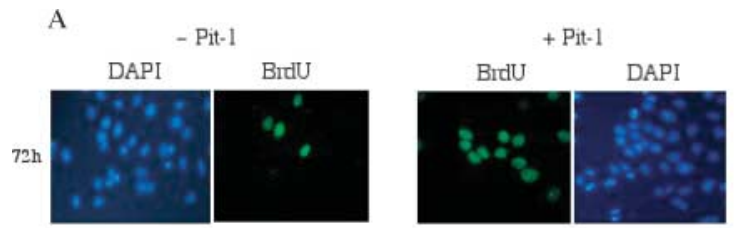

B

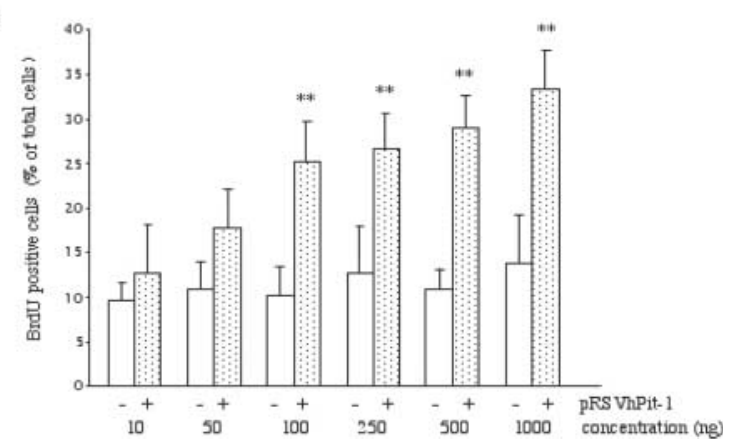

Figure 6 Incorporation of bromodeoxyuridine (BrdU) in pRSVhPit-1transfected MCF-7 cells and untransfected MCF-7 cells. MCF-7 cells were transfected with different concentrations of pRSVhPit-1 (from $10 \mathrm{ng}$ to $1000 \mathrm{ng} /$ well) or pRc/RSV (control cells) along with a puromycin-resistance-encoding vector ( $\mathrm{pEPuro}$ ). Cells were selected in $1 \mu \mathrm{g} / \mathrm{ml}$ puromycin for $72 \mathrm{~h}$, and then subjected to BrdU pulse labelling $(10 \mu \mathrm{mol} / \mathrm{l})$ for $30 \mathrm{~min}$. Incorporation of BrdU (an indicator of cell proliferation) was determined at $72 \mathrm{~h}$, by fluorescence microscopy of cells stained with an fluorescein isothiocyanate-conjugated anti-BrdU antibody and counterstained with 4,6-diamine-2phenylindole (DAPI). (A) Representative set of fluorescence microphotographs: MCF-7 cells transfected with $250 \mathrm{ng}$ pRSVhPit-1 vector (+Pit-1) or $250 \mathrm{ng} \mathrm{pRc} / \mathrm{RVS}$ empty vector (control cells, - Pit-1). Original magnifications $\times 40$. (B) Proliferation rate was calculated as the percentage of DAPI-positive nuclei that were also BrdU-positive. 国/+, pRSVhPit-1-transfected MCF-7 cells; $\square /-$, pRc/RSVtransfected, MCF-7 cells (mean values and S.D. bars). ${ }^{* \star} P<0.01$ compared with control cells. 
immunohistochemistry) in both normal human breast and invasive ductal mammary carcinomas. In addition, we found significantly increased Pit-1 mRNA expression in breast tumors compared with normal mammary tissue. In the western blots, we had no way of evaluating the concentrations of Pit-1 in relation to a protein standard, because Pit-1 was immunoprecipitated. Thus we cannot be absolutely certain that concentrations of Pit-1 protein are increased in breast tumors with respect to normal breast; however, our results strongly suggest that this is the case.

The possibility of the involvement of Pit-1 in the pathogenesis of pituitary tumors has been considered in previous studies. Some studies have not found any relation between Pit-1 expression and pituitary tumorigenesis (33), and have concluded that Pit-1 is overexpressed in PRL- and GH-secreting tumors to an extent consistent with the predominant cellular type of these adenomas (33); however, the findings of other studies suggest that Pit-1 is directly involved in pituitary cell proliferation (14), and possibly in the pathogenesis of pituitary adenomas $(12,13,34)$. The present results raise the possibility that Pit-1 may be similarly involved in cell proliferation and tumorigenesis in the human breast. We also found a dose-dependent increase in cell proliferation (as demonstrated by BrdU incorporation) in MCF-7 cells transfected with a Pit-1 expression vector, which indicates that the increase in cell proliferation is a consequence of the increase in Pit-1 expression, not vice versa. Indeed, it seems that small increases in the expression of Pit-1 may induce significant increases in cell proliferation. In fact, in the extrapituitary cell line HL-60 (a human myeloid leukaemic cell line), expression of Pit-1 is specifically associated with cell proliferation, supporting the idea that one of the functions of non-pituitary Pit-1 may be the control of cell proliferation (35). Thus the greater expression of Pit-1 that we observed in mammary tumors compared with normal breast may reflect involvement of Pit-1 in the regulation of tumour growth.

Besides the possible direct involvement of Pit-1 in the pathogenesis of mammary tumors, two main pituitary hormones regulated by Pit-1, namely GH and PRL, are expressed in human breast tissue and cell lines $(18,20,21,25)$. However, the role of Pit-1 in extrapituitary tissues is not completely understood, and in some cases the expression of GH and PRL seems to be Pit-1-independent and regulated by other transcription factors (36); this seems to be the case in murine bone marrow cells from hypopituitary Snell dwarf mice, in which pituitary Pit-1 does not bind DNA normally, and in which GH concentrations were found to be similar to those in bone marrow cells from normal mice (37). Similarly, although Pit-1 is required for the pituitary expression of PRL, expression of the PRL gene occurs in uterine sarcoma cells in the absence of the Pit-1 gene (38). However, other authors have suggested that extrapituitary Pit-1 is involved, like pituitary Pit-1, in the control of GH and PRL secretion $(31,32)$. In fact, it has been demonstrated that exogenous expression of Pit-1 in the corticotropic cell line AtT-20, which does not express GH endogenously, is capable of inducing endogenous $\mathrm{GH}$ mRNA and protein (39). In human mammary gland, and given that Pit-1 is expressed endogenously, it seems possible that GH and PRL may be regulated, as in the pituitary, by Pit-1 produced in the breast, and thus high concentrations of Pit-1 may induce increased concentrations of GH and PRL. This possibility, at least with respect to $\mathrm{GH}$, is supported by the present results: specifically, overexpression of Pit-1 in MCF-7 cells significantly increased GH protein concentrations and mRNA levels. In addition, cotransfection experiments indicated that overexpression of Pit-1 in MCF-7 cells dose-dependently increases the transcriptional activity of the $\mathrm{GH}$ promoter. However, overexpression of Pit-1 did not appear to increase IGF-I mRNA levels, thus suggesting that the observed effects of Pit-1 on cell proliferation are the result of either a direct effect of Pit-1 or an effect mediated by $\mathrm{GH}$ or other factors (e.g. PRL; see below), and not an effect mediated by IGF-I.

The findings of several studies have suggested a possible relationship between the GH-IGF-I axis, PRL and mammary tumor formation (for reviews see 16, 17, 40, 41). Patients with breast cancer exhibit increased serum concentrations of GH (42) and IGF-I (43), and autocrine production of human GH increases cell numbers in mammary carcinoma as a consequence of both increased mitogenesis and decreased apoptosis (44, 45). Increased expression of $\mathrm{GH}$ with respect to normal mammary gland has been associated with proliferative disorders, including invasive ductal carcinoma (46). In the case of PRL, it has been reported that as many as $44 \%$ of patients with metastatic breast disease have been hyperprolactinaemic at some stage during the course of the disease (47), and the presence of bioactive PRL in human breast cancer cells acts in an autocrine manner to stimulate cell proliferation (48). Transgenic mice have been used to study the effects of high concentrations of human GH and PRL. Female mice transgenic for hGH $(49,50)$ or for PRL (51) develop malignant mammary adenocarcinomas and, in spite of the fact that the human PRL receptor is activated by both PRL and GH (52), it seems that tumor development is caused by activation of the prolactin receptor (51). From our present findings, we cannot evaluate whether Pit-1 acts directly or through increased GH (or PRL?) secretion, but it seems likely that, if these two hormones are regulated by Pit-1, the suppression of Pit-1 may inhibit the expression of both. Certainly, though, future studies will be needed to explore further the role of Pit-1 in human breast cancer.

In conclusion, in this study we have demonstrated that the Pit-1 transcription factor and its mRNA are 
present in both normal human mammary gland and invasive ductal mammary carcinomas. We also found that the expression of Pit- 1 is significantly greater in breast carcinoma tissue than in normal breast. Moreover, in the MCF-7 human adenocarcinoma cell line, as in the pituitary gland, Pit-1 activates GH gene transcription and induces cell proliferation.

\section{Acknowledgements}

We thank Drs JL Castrillo, M Delhase and EP Slater for plasmids, and Dr A Parlow for anti-hGH antibody. The authors are grateful to Dolores F. Roel for expert technical assistance, and to Lourdes Loidi and Celsa Quinteiro for sequencing the Pit-1 PCR.

This work was supported by grants from the Xunta de Galicia (PGIDITO3PXIB20802PR and PGIDITO2PXIB20801PR), and the Fondo de Investigaciones Sanitarias, Ministerio de Sanidad (PI040518), Spain.

\section{References}

1 Simmons DM, Voss JW, Ingraham HA, Holloway JM, Broide RS, Rosenfeld MG \& Swanson LW. Pituitary cell phenotypes involve cell-specific Pit-1 mRNA translation and synergistic interactions with other classes of transcription factors. Genes and Development $19904695-711$.

2 Dollé P, Castrillo JL, Theill LE, Deerinck T, Ellisman M \& Karin M. Expression of GHF-1 protein in mouse pituitaries correlates both temporally and spatially with the onset of growth hormone gene activity. Cell $1990 \mathbf{6 0} 809-820$.

3 Lefevre C, Imagawa M, Dana S, Grindlay J, Bodner M \& Karin M. Tissue specific expression of the human growth hormone gene is conferred in part by the binding of a specific trans-acting factor. EMBO Journal 19876 971-981.

4 Nelson C, Albert VR, Elsholtz HP, Lu LI-W \& Rosenfeld MG. Activation of cell-specific expression of rat growth hormone and prolactin genes by a common transcription factor. Science 1988239 1400-1405.

5 Theill LE \& Karin M. Transcriptional control of GH expression and anterior pituitary development. Endocrine Reviews $1993 \mathbf{1 4}$ $670-689$.

6 Li S, Crenshaw EB, Rawson EJ, Simmons DM, Swanson LW \& Rosenfeld MG. Dwarf locus mutants lacking three pituitary cell types result from mutations in the POU-domain gene Pit-1. Nature $1990347528-533$.

7 Lin C, Lin SC, Chang CP \& Rosenfeld M. Pit-1-dependent expression of the receptor for growth hormone releasing factor mediates pituitary cell growth. Nature $1992 \mathbf{3 6 0} 765-768$.

8 Lin S-C, Li S, Drolet DW \& Rosenfeld MG. Pituitary ontogeny of the Snell dwarf mouse reveals Pit-1-independent and Pit-1-dependent origins of the thyrotrope. Development 1994120 515-522.

9 Chen R, Ingraham HA, Treacy MN, Albert VR, Wilson L \& Rosenfeld MG. Autoregulation of Pit-1 gene expression is mediated by two cis-active elements. Nature $1990346583-586$.

10 McCormick A, Brady H, Theill LE \& Karin M. Regulation of the pituitary specific homeobox gene GHF-1 by cell autonomous and enviromental cues. Nature 1990345 829-832.

11 Delhase M, Vergani P, Malur A, Velkeniers B, Tengels E, Trouillas J \& Hooghe-Peters EL. Pit-1/GHF-1 expression in pituitary adenomas: further analogy between human adenomas and rat SMtTW tumours. Journal of Molecular Endocrinology 199311 $129-139$.

12 Asa SL, Puy LA, Lew AM, Sundmark VC \& Elsholtz HP. Cell typespecific expression of the pituitary transcription activator Pit-1 in the human pituitary and pituitary adenomas. Journal of Clinical Endocrinology and Metabobolism 199377 1275-1280.

13 Sanno N, Teramoto A, Matsuno A \& Osamura Y. Expression of human Pit-1 product in the human pituitary and pituitary adenomas. Archives of Pathology and Laboratory Medicine 1996120 $73-77$.

14 Castrillo JL, Theill L \& Karin M. Function of the homeodomain protein GHF1 in pituitary cell proliferation. Science 1991253 97-199.

15 Lantinga-van Leeuwen IS, Oudshoorn M \& Mol JA. Canine mammary growth hormone gene transcription initiates at the pituitary-specific start site in the absence of Pit-1. Molecular and Cellular Endocrinology 1999150 121-128.

16 Wennbo H \& Törnell J. The role of prolactin and growth hormone in breast cancer. Oncogene 200019 1071-1076.

17 Laban C, Bustin SA \& Jenkins PJ. The GH-IGF-I axis and breast cancer. Trends in Endocrinology and Metabolism 200314 28-34.

18 Purnell DM, Hillman EA, Heatfield BM \& Trump BF. Immunoreactive prolactin in epithelial cells of normal and cancerous human breast and prostate detected by the unlabeled antibody peroxidase-antiperoxidase method. Cancer Research 198242 2317-2324.

19 Sobrier ML, Duquesnoy P, Duriez B, Amselem S \& Goossens M. Expression and binding properties of two isoforms of the human growth hormone receptor. FEBS Letters 1993319 16-20.

20 Mol JA, Henzen-Logmans SC, Hageman P, Misdorp W, Blankenstein MA \& Rijnberk A. Expression of the gene encoding growth hormone in the human mammary gland. Journal of Clinical Endocrinology and Metabolism 199580 3094-3096.

21 Clevenger CV, Chang W, Ngo W, Pasha T, Montone KT \& Tomaszewski JE. Expression of prolactin and prolactin receptor in human breast carcinoma. American Journal of Pathology 1995 $146695-705$.

22 Mertani HC, Garcia-Caballero T, Lambert A, Gerard F, Palayer C, Boutin JM, Vonderhaar BK, Waters MJ, Lobie PE \& Morel G. Cellular expression of growth hormone and prolactin receptors in human breast disorders. International Journal of Cancer 199879 $202-211$.

23 Ng ST, Zhou J, Adesanya OO, Wang J, LeRoith D \& Bondy C. Growth hormone treatment induces mammary gland hyperplasia in aging primates. Nature Medicine 20003 1141-1144.

24 Hankinson SE, Willet WC, Colditz GA, Hunter DJ, Michaud DS, Deroo B, Rosner B, Speizer FE \& Pollak M. Circulating concentrations of insulin-like growth factor-I and risk of breast cancer. Lancet $19983511393-1396$.

25 Gil-Puig C, Blanco M, García-Caballero T, Segura C \& PerezFernandez R. Pit-1/GHF-1 and GH expression in the MCF-7 human breast adenocarcinoma cell line. Journal of Endocrinology $2002173161-167$.

26 Schmittgen TD \& Zakrajsek BA. Effect of experimental treatment on housekeeping gene expression: validation by real-time, quantitative RT-PCR. Journal of Biochemical and Biophysical Methods $2000 \mathbf{4 6} 69-81$.

27 Seoane S, Alonso M, Segura C \& Perez-Fernandez R. Localization of a negative vitamin $\mathrm{D}$ response sequence in the human growth hormone gene. Biochemical and Biophysical Research Communications $2002292250-255$.

28 Voss JW, Yao T-P \& Rosenfeld MG. Alternative translation initiation site usage results in two structurally distinct forms of Pit-1. Journal of Biological Chemistry 1991266 12832-12835.

29 Karin M. Transcriptional control and integration of cell-autonomous and environmental cues during development. Current Opinion in Cell Biology 19902 996-1002.

30 Ruvkun G. A molecular growth industry. Nature 1992360 $711-712$.

31 Bamberger AM, Bamberger CM, Pu LP, Puy LA, Loh YP \& Asa SL. Expression of Pit-1 messenger ribonucleic acid and protein in the human placenta. Journal of Clinical Endocrinology and Metabolism $1995802021-2026$. 
32 Schanke JT, Conwell CM, Durning M, Fisher JM \& Golos TG. Pit-1/Growth hormone factor 1 splice variant expression in the rhesus monkey pituitary gland and the rhesus and human placenta. Journal of Clinical Endocrinology and Metabolism 1997 82 800-807.

33 Pellegrini I, Barlier A, Gunz G, Figarella-Branger D, Enjalbert A, Grisoli F \& Jaquet P. Pit-1 gene expression in the human pituitary and pituitary adenomas. Journal of Clinical Endocrinology and Metabolism $199479189-196$.

34 Delhase M, Vergani P, Malur A, Hooghe-Peters EL \& Hooghe RJ The transcription factor Pit-1/GHF-1 is expressed in hemopoietic and lymphoid tissues. European Journal of Immunology 199323 951-955.

35 Costoya JA, García-Barros M, Gallego R, Señarís R, Arce VM \& Devesa J. Correlation of Pit-1 gene expression and Pit-1 content with proliferation and differentiation in human myeloid leukemic cells. Experimental Cell Research $1998 \mathbf{2 4 5} 132-136$.

36 Harvey S, Azumaya Y \& Hull KL. Pituitary and extrapituitary growth hormone: Pit-1 dependence? Canadian Journal of Physiology and Pharmacology 200078 1013-1028.

37 Kooijman R, Malur A, Van Buul-Offers SC \& Hooghe-Peters EL. Growth hormone expression in murine bone marrow cells is independent of the pituitary transcription factor Pit-1. Endocrinology $19971383949-3955$.

38 Gellersen B, Kempf R, Telgmannn R \& DiMattia GE. Pituitary-type transcription of the human prolactin gene in the absence of Pit-1. Molecular Endocrinology $19959887-901$.

39 Kurotani R, Yoshimura S, Iwasaki Y, Inoue K, Teramoto A \& Osamura RY. Exogenous expression of Pit-1 in AtT-20 corticotropic cells induces endogenous growth hormone gene transcription. Journal of Endocrinology 2002172 477-487.

40 Vonderhaar BK. Prolactin involvement in breast cancer. EndocrineRelated Cancer 19996 389-404.

41 Clevenger CV, Furth PA, Hankinson SE \& Schuler LA. The role of prolactin in mammary carcinoma. Endocrine Reviews $20032 \mathbf{4}$ $1-27$.

42 Emerman JT, Leahy M, Gout PW \& Bruchovsky N. Elevated growth hormone levels in sera from breast cancer patients. Hormone and Metabolic Research 198517 421-424.

43 Peyrat JP, Bonneterre J, Hecquet B, Vennin P, Louchez MM, Fournier C, Lefebvre J \& Demaille A. Plasma insulin-like growth factor-1 (IGF-1) concentrations in human breast cancer. European Journal of Cancer 1993 29A 492-497.
44 Kaulsay KK, Mertani HC, Törnell J, Morel G, Lee K-O \& Lobie P. Autocrine stimulation of human mammary carcinoma cell proliferation by human growth hormone. Experimental Cell Research $199925035-50$.

45 Kaulsay K, Mertani HC, Lee K-O \& Lobie P. Autocrine human growth hormone enhancement of human mammary carcinoma cell spreading is Jak2 dependent. Endocrinology $2000 \mathbf{1 4 1}$ $1571-1584$.

46 Raccurt M, Lobie PE, Moudilou E, Garcia-Caballero T, Frappart L, Morel G \& Mertani HC. High stromal and epithelial human GH gene expression is associated with proliferative disorders of the mammary gland. Journal of Endocrinology 2002175 307-318.

47 Holtkamp W, Nagel GA, Wander HE, Rauschecker HF \& VonHeyden D. Hyperprolactinemia is an indicator of progressive disease and poor prognosis in advanced breast cancer. International Journal of Cancer 198434 323-328.

48 Ginsburg E \& Vonderhaar BK. Prolactin synthesis and secretion by human breast cancer cells. Cancer Research $1995 \mathbf{5 5}$ 2591-2595.

49 Törnell J, Rymo L \& Isaksson OGP. Induction of mammary adenocarcinomas in metallothionein promoter-human growth hormone transgenic mice. International Journal of Cancer 199149 114-117.

50 Bartke A, Cecim M, Tang K, Steger RW, Chandrashekar V \& Turin D. Neuroendocrine and reproductive consequences of overexpression of growth hormone in transgenic mice. Proceedings of the Society for Experimental Biology and Medicine 1994206 345-359.

51 Wennbo H, Gebre-Medhin M, Gritli-Linde A, Ohlsson C, Isaksson O \& Törnell J. Activation of the prolactin receptor but not the growth hormone receptor is important for induction of mammary tumors in transgenic mice. Journal of Clinical Investigation 1997 $1002744-2751$.

52 Goffin V, Shiverick KT, Kelly PA \& Martial JA. Sequence-function relationships within the expanding family of prolactin, growth hormone, placental lactogen, and related proteins in mammals. Endocrine Reviews 199617 385-410.

Received 11 March 2005

Accepted 13 May 2005 